\title{
Employment Guarantee Scheme for rural development a model of Maharashtra (India) a lesson for developing Countries
}

\author{
A. M. Ingle \\ PIRENS Institute of Business Management Administration, \\ Loni(Bk)MS, India
}

\begin{abstract}
The Employment Guarantee Scheme (EGS) of Maharashtra state (India) may be taken as a model of a public works programme. It guarantees employment to the entire rural household willing to do manual unskilled work at minimum wages. If employment cannot be provided the Government is obliged to make payment of unemployment allowance to unemployed persons per day. Moreover this scheme is non-inflationary in nature as all the projects under it are financed out of taxation and State Government contribute to the EGS fund.

Recently purchasing power has been transferred from the urban rich (professional taxes, etc.) to the rural poor. The assets created under the scheme are productive and longer lasting leading to the generation of rural employment and income flows in the future, i.e. for rural development.

Keywords: Employment Guarantee Scheme, Rural Employment Guarantee Act EGS in Maharashtra, reforms in EGS.
\end{abstract}

\section{Introduction}

It recent years, Rural public works programmes (RPW) have been used to provide employment for the poor to deal with situations such as famine and drought in rural areas in many developing countries. The objectives of RPW are to provide employment and to create "public good" such as physical infrastructure development. South Asian countries with large population, high unemployment and poverty such as India, Bangladesh \& Pakistan have included employment through RPW at the core of their anti-poverty strategy. RPWs have self-targeting advantage along with equalizing geographic disparity by generating infra-structural assets. 
In India, the Employment Guarantee Scheme (EGS) of Maharashtra is a unique model of a public works programme. It guarantees employment to all rural adjust over 18 years who are willing to do manual unskilled work on a piece rate basis. Hence, this paper is a modest attempts to suggest the applications of Maharashtra state model of EGS at all India level to Concerned state specific modifications and highlight its lessons to global developing world especially Afro Asian countries, through Rural Employment Guarantee, achieve the goal of Rural development.

In Bangladesh, the national food for work (FFW) programme is to provide employment and income in bleak season to rural labourers. It has been argued that if there had been a RWP programme during 1974 famine in Bangladesh, a great many people could have been saved from starvation \& impoverishment unlike in other countries.

To augment the supply of loanable funds at affordable rates to the poor, group-based lending programmes have recently become popular in South Asia and have taken a quantum leap since the success of the Grameen Bank in Bangladesh. These programmes seek to provide credit and other services to poor people who lack access to formal credit institutions. In the context of rural development, their role has been mainly to alleviate poverty at the household level, rather than the development of community infrastructure or to improve access to public services. Microcredit programmes typically enable the poor to acquire income-generating assets by providing access to credit, marketing and other inputs.

Bangladesh, which inspired the microcredit revolution in South Asia, established the Grameen Bank in 1983 under the pioneering leadership of Dr. M. Yunus, has two other microcredit programmes: the Bangladesh Rural Advancement Committee (BRAC), and the Bangladesh Rural Development Board's Rural Development Programme, which engage in a variety of other developmental activities. A United Nations study (UNDP/UNOPS/APDC 1996) on the outreach of 39 microfinance institutions/programmes in 12 countries of Asia found that they covered a total of 5.1 million households. Of this, about 4.5 million households were in Bangladesh and only 0.6 million households in the rest of the region.

The main impetus to microfinance has so far come from NGO's, primary rural support programmes. In view of the heightened demand for microcredit in poor communities, the Government and donors have realized the need for ensuring the supply of sufficient funds on a sustainable and institutionalized basis.

In some countries (Like Zambia) payment of wages in kind rendered the program less attractive to men (who like cash wages) and enabled more women to join the program.

RPW in Pakistan has failed to smooth consumption in periods of high unemployment in past due to their capture by patronage politics. At present, less than $5 \%$ of the credit needs of the rural poor are estimated to be met by micro credit programmes. 
China has focused on this problem very recently with a concerted effort from February last. The approach being followed is interesting. First, there's a thrust on creating infrastructure, to provide modern access to rural areas. Second, there is an effort to create industrial infrastructure. "The only way to fight desertification is to make the area industrial" announces a party leader, "then it is no longer a desert". State-level banks are providing the capital for setting up of industrial units, which would be owned by the state at the local level. Finally, there's a training programme to train rural youth to work in these factories. Even in areas where there is no natural raw material to process, low cost manufacturing industry is being introduced. In short, the focus is on upgrading skills, provision of capital for production of goods for the market and the infrastructure to reach the products to the market.

In India, from the 4th century B.C. when the ancient Indian political economist Kautilya, wrote his Arthasatra, there has been emphasis on public relief works in famines and employment on public works later became the main and most effective element of strategies for famine prevention. In post independent era, there are large sized major programmes such as the "Employment Assurance Scheme" at national level and "Employment Guarantee Scheme" (EGS) of Maharashtra Govt 1977 recommended by the UNDSP'S programme in developing world. EGS in Maharashtra Govt. originated from a pilot project in Tasgaon Block of Sangli District and was operated as an Integrated Area Development scheme; originally conceived by Late. V.S. page, Gandhian Leader and activist.

The problem of rural unemployment has assumed serious proportions since the adoption of New Economic Policy (NEP) by Government of India in 1991. The united progressive Alliance (UPS) Government has aptly proposed an enactment of "National Rural Employment Guarantee Act" which differs from Maharashtra EGS Act, 1977. In the proposed National EGS Act, the coverage is limited to only one rural poor (probably, all below poverty line rural families in India) While in EGS act in Maharashtra, all able bodied rural persons with no limit of number from the family are covered.

Similarly, in the National EGS Act, employment is guaranteed only for 100 days in a year while in Maharashtra Act, employment is guaranteed for the entire year and not for a specific period. Further of the Govt. is obliged to pay an unemployment allowance of Rs. 2/- per head per day.

\section{Background of NEG Act}

The policy agenda outlined in the common Minimum programme of the UPA government begins with following pledge;

"The UPA government will immediately enact a National Employment Guarantee Act. This will provide a legal guarantee for at least 100 days of employment to being with on asset-creating public works programmes every year at minimum wages for least one able-bodied person in very rural, urban poor and lower middle-class household" 


\section{Unit costs}

It is assumed that each person-day of employment generated costs of one hundred rupees at 2004-05 prices. This would roughly consist of Rs 60 for wages and Rs 40 for the non-labour, including administrative costs. The figure of Rs 60 for the wage component is quite close to population-weighted average of statespecific statutory minimum wages for agricultural labours in different states.

The assumed ratio of non-labour costs to total cost, namely $40 \%$ is in line with recent norms under public employment programmer such as Sampoorna Grameen Rozgar Yojana (SGRY)

Not, however, that this $40 \%$ ratio is significantly higher than the corresponding ratio in Maharashtra under the Employment Guarantee Scheme (EGS): about $30 \%$ on average since the inception of the EGS in 1975-1976, and $25 \%$ during the last five years for which data are available. With lower benchmarks for the non-labour component, the unit costs would be correspondingly lower. For instance, with lower ratio of $25 \%$ for non-labour costs, the unit costs would come down to Rs 80 per person-day of employment.

Table 1: Cost of a National Rural Employment Guarantee Act: baseline estimate.

(Amount in Rs.Crs.)

\begin{tabular}{|l|r|}
\hline Particulars & Amount \\
\hline $\begin{array}{l}\text { Total rural population, 2001 (crores) } \\
\text { Proportion of rural population below the poverty line }{ }^{\mathrm{a}}(26.8 \%)\end{array}$ & 74.2 \\
\hline${\text { Estimated rural population below the poverty line } 20001^{\text {b (crores) }}}^{\text {c }}$ & 20 \\
\hline Total number of rural households below the poverty line ${ }^{\mathrm{c}}$ (crores ) & 4 \\
\hline $\begin{array}{l}\text { Total person-days to be generated, assuming "100 days per poor } \\
\text { households on average }\end{array}$ & 400 \\
\hline Cost per day, at 2004-5 prices (Rs) & 100 \\
\hline Total cost of the employment Guarantee Programme & 40,000 \\
\hline Total cost as percentage of India's GDP in 2004-5 & e \\
\hline
\end{tabular}

${ }^{a}$ Official estimate (planning commission) for 1999-2000.

${ }^{\mathrm{b}} 26.8 \%$ of 74.2 crores.

${ }^{\mathrm{C}}$ Assuming an average household size of 5 .

${ }^{\mathrm{d}}$ See above text for further discussion of this benchmark.

${ }^{\mathrm{e}} \mathrm{GDP}=$ Rs. 3104,857 crores (budget Estimate, reported in Government of India 2004, P. 33).

Note: These calculations assume that there has been no decline (more precisely, no change in the absolute number of poor households since 2001. This is likely to introduce a small upward bias in the cost estimates, sine the trend decline in poverty, according to official estimates, implies a decline in the number of poor households over time. 
Table 2: $\quad$ Cost of a National Rural Employment Guarantee Act: with phased implementation over four years.

\begin{tabular}{|c|c|c|c|c|}
\hline & $2005-2006$ & $2006-2007$ & $2007-2008$ & 2008-2009 \\
\hline $\begin{array}{l}\text { GDP at } 2004-2005 \text { prices }^{\mathrm{a}} \\
\text { (Rs crores) }\end{array}$ & 3330881 & 3565383 & 3807857 & 4057701 \\
\hline $\begin{array}{l}\text { Number of districts to be } \\
\text { covered }\end{array}$ & 150 & 300 & 450 & 600 \\
\hline $\begin{array}{l}\text { Estimated "head-count } \\
\text { ratio" in the reference } \\
\text { districts, 1999-2000 }(\%)\end{array}$ & 45 & 38 & 32 & 27 \\
\hline $\begin{array}{l}\text { Estimated population } \\
\text { below Poverty line in } \\
\text { reference districts (crores) }\end{array}$ & & & & \\
\hline Persons & 8.35 & 14.10 & 17.81 & 20 \\
\hline Households & 1.67 & 2.82 & 3.56 & 4 \\
\hline $\begin{array}{l}\text { Employment generation @ } \\
100 \text { days per poor } \\
\text { household } \\
\text { (Crores) person-days per } \\
\text { year) }\end{array}$ & 167 & 282 & 356 & 400 \\
\hline $\begin{array}{l}\text { Cost per day, at 2004-2005 } \\
\text { prices (Rs) }\end{array}$ & 100 & 100 & 100 & 100 \\
\hline $\begin{array}{l}\text { Total cost at 2004-2005 } \\
\text { prices } \\
\text { (Rs crores) }\end{array}$ & 16,700 & 28,200 & 35,600 & 40,000 \\
\hline $\begin{array}{l}\text { Total cost as a ratio of } \\
\text { GDP }(\%)\end{array}$ & 0.50 & 0.79 & 0.93 & 0.99 \\
\hline
\end{tabular}

"Based on the projections of the recent "Kelkar Report" (Government of Indian, 2004), p.33, assuming a GDP deflator of 4.4\%, as in the Kelkar report (p.29).

${ }^{\mathrm{b}}$ Based on Deaton (2003), assuming that the Employment Guarantee Programme is gradually extended to the whole of India over four years, from the poorest districts to the less poor districts. The head-count ratio is the proportion of the population below the poverty line. The reason why the "head-count ratio of in "reference district" it is sharply declining over time is that the programme starts with the poorest districts.

${ }^{c}$ The estimates are obtained by combining the 1999-2000 headcount ratios with 2001 population figures, and assuming no change in the absolute number of poor households after 2001 (as in Table 2).

\section{Phased implementation}

The preceding calculations assume that the Employment Guarantee Programme is fully implemented in one go. In fact, draft Act provides for phased implementation over several years-two years according to the draft initially submitted to the National Advisory Council (NAC), five years in the revised NAC draft. In this note, it assumes phased implementation over four years, starting from 2005-2006. 
To estimate the cost implications of phased implantation over four year, the following assumptions are made:

Each year, starting in 2005-2006, one fourth of India's districts are added to the coverage of the Employment Guarantee Programme (EGP).

The poorest districts are covered first, and other districts are added in decreasing order of poverty

The EGP is to generate 100 days of employment per poor household on average.

The absolute number of poor households (in the absence of EGP employment) remains constant over time

It is to be noted that the last assumption implies a small upward bias in the cost estimates, since the absolute number of poor households is actually declining over time, according to official poverty figures. The resulting estimates are presented in Table 2 .

\section{Positive aspects of the EGS in Maharashtra (India)}

The EGS is underpinned by two Acts - The Maharashtra Employment Guarantee Act of 1977 that laid down details of how the scheme was to be implemented and Maharashtra state tax on professions, Trades, calling and employment Act, of 1975 that gave the financial mechanism through which it was to be supported. There are 5 specific taxes of which the most important is the professional tax. The State Govt. makes on contribution to the EGS find that matches the yield from these decimated taxes

The EGS mentioned above is non-inflationary in nature as all the projects under it are financed out of taxation. The purchasing power is transferred from the urban rich (Professional Tax) to the rural poor. The assets created under the scheme are productive in nature and lead to generation of employment and income flows in future.

\section{Functioning of "EGS" in Maharashtra State:}

Maharashtra State made the modest beginning of EGS for the first time during the year 1972-1973. Since then till recently the progress of the scheme can be judged on the basis of the following Tables 3-5.

Criticisms on the working of the EGS:

1. incorrect measurement;

2. cross checking on Muster \& Measurements;

3. payment in Absence of local Gram Panchayat Authorities;

4. non Display of wage Board/ Duplicate Muster;

5. carrying out works beyond 10\% Excess over Sanctioned Estimates;

6. late Arrival \& Early Departure of Laborers.

In addition to the above; one criticism of the EGS is that, despite the scheme's existence, poverty in Maharashtra has not declined more speedily than average. 
Table 3: Annual expenses and mandays employment of EGS in Maharashtra for the Period 1993-1994 to 2002-2003.

(Expenses in Rs. crores and man days figures in crores)

\begin{tabular}{|c|c|c|c|c|c|c|c|c|c|c|}
\hline 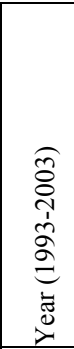 & 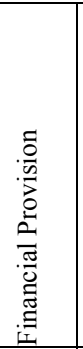 & 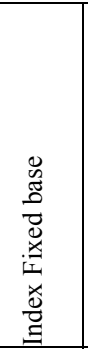 & 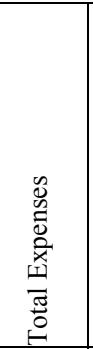 & 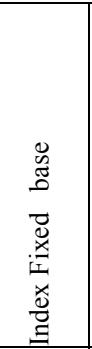 & 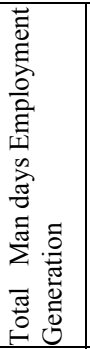 & 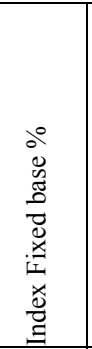 & 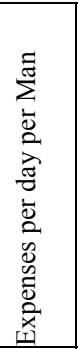 & 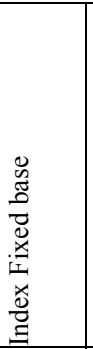 & 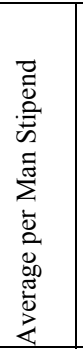 & 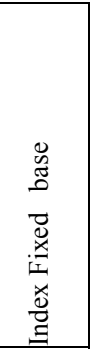 \\
\hline & & $\%$ & & $\%$ & & & & & $\mathrm{RS}$ & $\%$ \\
\hline 93-94 & 313.62 & 100 & 347.34 & 100 & 9.84 & 100 & 35.3 & 100 & 18.6 & 100 \\
\hline 94-95 & 413.15 & 131.74 & 383.15 & 110.31 & 9.42 & 95.73 & 40.77 & 115.50 & 28.51 & 153.28 \\
\hline $95-96$ & 450 & 143.49 & 443.75 & 127.76 & 9.7 & 98.58 & 45.75 & 129.60 & 28.82 & 154.95 \\
\hline $96-97$ & 418.25 & 133.36 & 336.75 & 96.95 & 9.01 & 91.57 & 40.7 & 115.30 & 28.49 & 153.17 \\
\hline $97-98$ & 360 & 114.79 & 353 & 101.63 & 9 & 91.46 & 39.22 & 111.10 & 28.63 & 153.92 \\
\hline 98-99 & 489 & 155.92 & 456.66 & 131.47 & 9.19 & 93.39 & 49.69 & 140.76 & 35.28 & 189.68 \\
\hline 99-00 & 495.25 & 157.91 & 493.97 & 142.22 & 9.49 & 96.44 & 52.03 & 147.39 & 39.04 & 209.89 \\
\hline $00-01$ & 667.03 & 212.69 & 578 & 166.41 & 11.12 & 113.01 & 52.55 & 148.87 & 39.5 & 212.37 \\
\hline $00-02$ & 669.1 & 213.35 & 914.65 & 263.33 & 16.17 & 164.33 & 56.56 & 160.23 & 45.28 & 243.44 \\
\hline $00-03$ & 850 & 271.03 & 889 & 255.95 & 15.45 & 157.01 & 57.54 & 163.00 & 46.03 & 247.47 \\
\hline Total & 5125.4 & 1634.27 & 5196.27 & 1496.02 & 108.39 & 1101.52 & 470.11 & 1231.76 & 338.18 & 1818.17 \\
\hline Avg. & 515.44 & 163.42 & 519.62 & 149.6 & 10.83 & 110.15 & 47.01 & 123.17 & 29.21 & 181.81 \\
\hline
\end{tabular}

(Source: Govt. of Maharashtra, Planning Development/EGS 9, 2003)

As more calculations can show, even if workers work full time on EGS, they cannot earn enough to cross the poverty line. The problem of poverty is much wider than the coverage of EGS.

In the 1998, with the doubling of the statutory minimum wage rate, the EGS piece rates were also doubled. There is some merit in the low wage argument if we want to concentrate on reducing the intensity of poverty.

\section{Reforms in the EGS}

Under the he EGS is now required to pay wages at the statutory minimum rates, which are higher than market rates. There is a need to have some parity between these two rates. The wage rate must be raised in such a way that a person working 300 days a year can lift him or her and dependents above the poverty line.

Apparently, there is accumulated surplus of nearly Rs. 2,000 crores in the employment Guarantee Fund. This fund can be utilized for paying higher wage rates and better infrastructure. 
Table 4: $\quad$ Purpose wise annual expenses of EGS 1991-2003.

(Amt. in Rs. crores and in percentage)

\begin{tabular}{|c|c|c|c|c|c|c|c|c|c|c|c|c|c|c|}
\hline \multirow[t]{2}{*}{ Year } & \multicolumn{2}{|c|}{ Irrigation } & \multicolumn{2}{|c|}{ Agriculture } & \multicolumn{2}{|c|}{$\begin{array}{l}\text { Afforesta- } \\
\text { tion }\end{array}$} & \multicolumn{2}{|c|}{ Roads } & \multicolumn{2}{|c|}{$\begin{array}{l}\text { Miscellan- } \\
\text { eous } \\
\text { Salaries } \\
\text {, } \\
\text { Allowances } \\
\text { etc. }\end{array}$} & \multicolumn{2}{|c|}{$\begin{array}{c}\text { Employment } \\
\text { Horticulture } \\
\text { Jawahar } \\
\text { Wells }\end{array}$} & \multicolumn{2}{|c|}{ Total } \\
\hline & $\%$ & Rs & $\%$ & Rs & $\%$ & Rs & $\%$ & Rs & $\%$ & Rs & $\%$ & Rs & $\%$ & Rs \\
\hline 90-91 & 15 & 35 & 13 & 32 & 17 & 39 & 19 & 46 & 23 & 54 & 14 & 32 & 100 & 239 \\
\hline 91-92 & 15 & 48 & 16 & 50 & 16 & 50 & 20 & 47 & 12 & 37 & 23 & 73 & 100 & 320 \\
\hline $92-93$ & 19 & 85 & 21 & 94 & 11 & 52 & 22 & 52 & 10 & 45 & 18 & 79 & 100 & 453 \\
\hline $93-94$ & 18 & 63 & 19 & 67 & 12 & 40 & 19 & 46 & 6 & 22 & 25 & 88 & 100 & 348 \\
\hline 94-95 & 14 & 55 & 23 & 89 & 9 & 34 & 15 & 36 & 17 & 66 & 21 & 82 & 100 & 384 \\
\hline $95-96$ & 13 & 58 & 27 & 119 & 7 & 32 & 12 & 28 & 18 & 79 & 24 & 105 & 100 & 444 \\
\hline 96-97 & 15 & 55 & 14 & 52 & 8 & 30 & 14 & 34 & 9 & 31 & 40 & 146 & 100 & 367 \\
\hline $97-98$ & 17 & 60 & 9 & 30 & 11 & 39 & 17 & 40 & 12 & 42 & 35 & 122 & 100 & 353 \\
\hline 98-99 & 17 & 76 & 7 & 31 & 12 & 53 & 23 & 56 & 8 & 36 & 34 & 154 & 100 & 457 \\
\hline 99-00 & 12 & 59 & 7 & 33 & 12 & 57 & 27 & 65 & 14 & 68 & 29 & 142 & 100 & 494 \\
\hline 00-01 & 9 & 53 & 14 & 80 & 13 & 75 & 28 & 67 & 9 & 49 & 27 & 153 & 100 & 578 \\
\hline 2-Jan & 22 & 197 & 14 & 124 & 11 & 102 & 32 & 76 & 5 & 44 & 17 & 155 & 100 & 915 \\
\hline 3-Feb & 12 & 109 & 26 & 234 & 10 & 86 & 28 & 68 & 8 & 72 & 15 & 136 & 100 & 889 \\
\hline Tot & 197 & 953 & 209 & 1035 & 147 & 689 & 277 & 661 & 149 & 645 & 320 & 1468 & 100 & 6239 \\
\hline Avg. & 20 & 95 & 21 & 104 & 15 & 69 & 28 & 66 & 15 & 65 & 32 & 147 & 100 & 624 \\
\hline
\end{tabular}

(Source: Govt. of Maharashtra, Planning Development/EGS 9, 2003)

Recent experience, however, suggests that there is a need for increase in EGS wages because these wage rates are lesser compared to programs like JRY. It has the support of all groups for varying reasons. These factors are responsible for sustainability of the programme.

A study on Jawahar Taluka of Thane district (Deshpande, 1998) shows that the existence of a receiving mechanism in the form of a labour organization namely Bhoomi Sena Helped in improving the delivery of the EGS benefits.

African countries can learn a lot from the experience of India in the prevention of famines. Some evaluations have shown that the EGS plans and implementation is dominated by bureaucracy due to lack of peoples' participation.

Similarly, emphasis has to be given on the promotion of horticulture. These area already models like Pani Panchayat, Relgaon Shiddhi, etc in the area of conservation of water.

A number of cases of corruption have been cited in the reports of the legislature committee on the EGS from time to time. Involvement of NGOs and local people can only reduce the corruption 
Table 5: $\quad$ Year wise and month wise attendance of workers on EGS for the period 1993 to 2003 .

\begin{tabular}{|c|c|c|c|c|c|c|c|c|c|c|}
\hline \multirow[b]{2}{*}{ 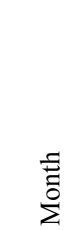 } & \multicolumn{9}{|c|}{ Per month per day attendance of workers } & \multirow[b]{2}{*}{ 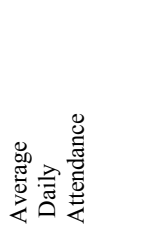 } \\
\hline & $\frac{\stackrel{\Xi}{\sigma}}{\frac{1}{\sigma}}$ & $\frac{2}{\frac{2}{a}}$ & $\frac{\stackrel{2}{2}}{2}$ & $\begin{array}{l}\frac{\hat{a}}{a} \\
\text { 。ั }\end{array}$ & $\frac{\stackrel{\circ}{\sigma}}{\frac{1}{\sigma}}$ & 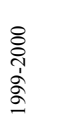 & 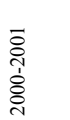 & 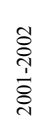 & 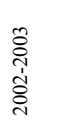 & \\
\hline Apr & 3.35 & 1.86 & 2.92 & 1.86 & 1.08 & 1.71 & 1.4 & 4.86 & 2.56 & 21.6 \\
\hline May & 3.85 & 2.23 & 3.18 & 1.82 & 1.19 & 1.97 & 1.68 & 5.85 & 3.37 & 25.14 \\
\hline Jun & 3.91 & 2.03 & 3.5 & 1.65 & 1.3 & 1.86 & 1.48 & 4.54 & 3.45 & 23.72 \\
\hline July & 2.98 & 1.23 & 2.83 & 1.32 & 0.68 & 1.14 & 0.88 & 2.18 & 1.71 & 14.95 \\
\hline Aug & 2.22 & 1.04 & 1.72 & 0.86 & 0.59 & 0.87 & 0.69 & 2.04 & 1.42 & 11.45 \\
\hline Sep & 1.96 & 1.06 & 1.48 & 0.63 & 0.7 & 0.7 & 0.76 & 2.58 & 1.18 & 11.05 \\
\hline Oct & 1.32 & 1.35 & 1.09 & 0.49 & 0.63 & 0.62 & 0.8 & 1.94 & 1.24 & 9.48 \\
\hline Nov & 1.01 & 1.47 & 0.89 & 0.49 & 0.53 & 0.57 & 0.93 & 1.69 & 1.03 & 8.61 \\
\hline Dec & 1.06 & 2.06 & 1.1 & 0.52 & 0.73 & 0.9 & 1.6 & 2.21 & 2.06 & 12.24 \\
\hline Jan & 1.34 & 2.59 & 1.17 & 0.69 & 1.17 & 1.05 & 2.37 & 2.56 & 3.25 & 16.19 \\
\hline Feb & 1.5 & 2.85 & 1.31 & 0.89 & 1.43 & 1.34 & 3.44 & 2.89 & 4.67 & 20.32 \\
\hline Mar & 1.75 & 2.93 & 1.62 & 1.06 & 1.43 & 1.58 & 4.35 & 2.87 & 5.33 & 22.92 \\
\hline Tot & 26.25 & 22.7 & 22.81 & 12.28 & 11.46 & 14.31 & 20.38 & $\begin{array}{r}36.2 \\
1\end{array}$ & 31.27 & 197.67 \\
\hline Avg & 2.18 & 1.89 & 1.9 & 1.85 & 1.14 & 0.95 & 1.69 & 3.01 & 2.6 & 16.46 \\
\hline
\end{tabular}

(Source: Govt. of Maharashtra, Planning Development/EGS 9, 2003)

\section{Conclusions}

This Shift of emphasis from community assets has important implications for the cost-effectiveness of EGS in reducing poverty also. There are other serious concerns relating to inadequate planning and inability of smallholders in raising their share of the financial contribution. Finally, as noted earlier, a better option would be to overcome credit market imperfection through self-help groups.

The employment guarantee law should not be considered a welfare measure or dole for the "poor" villagers, as conceived under the erstwhile HMS. It could be treated as an opportunity to invest in the creation of public good through manual as well as mental labour, the latter devoted largely to education. This will reduce migration of young persons to cities. The forthcoming law should be used as an investment in education infrastructure, and not perceived as something that would divert funds meant for these vital sectors, the development of which would bridge the gap between growing urban Indian and stagnating Rural Bharat. 
Employment Guarantee is the only powerful and potent instrument for generation of employment opportunities and making the employment available to the rural folk, which in turn, is the surest means of Rural Development.

\section{References}

[1] Bhalchendra Mungekar, The Economy of Maharashtra, Publisher, Dr. Ambedkar Institute of Social and Economic Change, Mumbai, 2003.

[2] S. Mahrndra Dev, Employment Guarantee Scheme: Lesson for development Policy, book edited by Bhalchandra Mungekar.

[3] R.P. Kurulkar, Rural Employment Guarantee Scheme AND LANDLESS Agriculture Labour, Himalaya publishing house, Mumbai 1989.

[4] Institute of development, Case study employment studies, University of Sussex.

[5] Planning Commission, Academic foundation on labour and employment report 2002, New Delhi.

[6] Raghav Gaiha, Is there a case for the Employment Guarantee Scheme in India? ASARC working paper 2004-09.

[7] Alderman Horald, Food subsidies and the poor, essay on poverty 1991.

[8] www.gogool.com

[9] www.yahoo.com

[10] www.rediffmail.com 